\title{
An update on the surgical use of tissue
}

\author{
Ruth M. Warwick
}

(C) Springer Science+Business Media B.V. 2009

The Tissue and Cells Directives (Directive 2004/23/ EC, Commission Directive 2006/17/EC and Commission Directive 2006/86/EC) require that those working in tissue and cell facilities are trained. Clearly an understanding of the use of tissues and cells is a requirement to fulfil this obligation, so on 10th April 2008 the British Association for Tissue Banking (BATB) held an educational meeting, called 'An Update in Use of Tissue from Surgical Opinion Leaders'. This meeting was designed to meet the requirements of the clinical aspects of the tissue banking module of the Specialist Certificate, which was set up in collaboration between the British Association for Tissue Banking and British Blood Transfusion Society.

The surgeons who were invited to speak at the meeting were asked to provide the tissue banking professionals with an update on current clinical practice in transplantation and to include in their presentation a short history of the use of allografts, a current transplant or implant overview of their field and to review specific severe adverse reactions that might occur with the use of the allografts which they were implanting. They were further asked to undertake horizon scanning about the future of allografts in clinical practice.

R. M. Warwick ( $₫)$

NHS Blood and Transplant, London, England, UK

e-mail: ruth.warwick@nhsbt.nhs.uk
The meeting was very well received by the tissue bankers and received very high evaluations from attendees. The content was considered to be of value, not only to tissue bankers but also to regulators and surgeons working in the field. For this reason it was decided to invite the surgeon speakers, or where that was not possible a colleague of theirs, to write a paper reflecting each of the talks of that day for publication in a Special Issue of the Journal of Cell and Tissue Banking. This issue therefore contains papers on the use of allograft blood vessels from Dominic Dodd, the use of amnion, limbal stem cells and autologous tears in eye surgery from Saaeha Rauz and Valerie Saw, another article, also on the ocular side, about the use of ophthalmic tissues, including cornea and cells from the limbus in eye surgery from Stephen Kaye's group, which has also produced, an article on adverse event reporting - a model that is used in the UK that may be suitable as a template for other jurisdictions. There is also an article on the use of allograft heart valves by David Barron and Natasha Khan and another article on the use of bone allografts from Iain McNamara. Ian McDermott and Alan Getgood with Steve Bollen complete the orthopaedic side with articles on meniscus and tendons in orthopaedic surgery. Jorge Leon-Villapalos and colleagues have contributed an article on the use of allograft skin and allograft alternatives in burns surgery.

Together this collection of papers on the use of allografts in surgery in many different disciplines will provide tissue bankers with an overview from 
surgeon users of tissues, demonstrating the great contribution that tissue banking makes to surgery and also the synergies that can exist when the partnership between surgeons and their tissue facilities ensure the appropriateness of the grafts produced. It also closes the loop to provide clinical governance and feedback on outcomes. Hopefully this will further stimulate review of graft service provision and greater understanding to improve safety and efficacy of grafts, their relevance in a changing world and closer dialogue and cooperation between tissue bankers and surgeons.

Ruth M. Warwick

BATB President (2006-2008) 